\begin{abstract}
"Mircea cel Batran" Naval Academy Scientific Bulletin, Volume XIX - 2016 - Issue 1
Published by "Mircea cel Batran" Naval Academy Press, Constanta, Romania /I The journal is indexed in: PROQUEST / DOAJ / DRJI / JOURNAL INDEX / I2OR / SCIENCE LIBRARY INDEX / Google Scholar / Crossref /

Academic Keys / ROAD Open Access / OAJI / Academic Resources / Scientific Indexing Services / SCIPIO
\end{abstract}

\title{
MARITIME SPATIAL PLANNING IN THE INTEREST OF PROTECTION
}

\author{
Petar KLIMOV ${ }^{1}$ \\ ${ }^{1}$ Assistant Professor Organization and Management of Naval Formations, "Nikola Vaptsarov" Naval \\ Academy - Varna
}

\begin{abstract}
The providing of activities in the sea areas is associated with ensuring security environment and safety. Much of the safety activities are serving security purposes. The vice versa is also possible and the activities could be complementary. Therefore, this requires examining the system of safety as composed of two complementary components.
\end{abstract}

\section{Keywords: maritime spatial planning, maritime security and safety, environmental protection}

At the beginning of the $X X I$ century, due to the dynamic changes in the Black Sea region, the challenges facing the supporting of security and safety at sea increased. The ensuring of the national interests at sea is realized by conducting active control in the national maritime territories, in this sense, control is defined as:

- a set of adequate to the world and regional situation events and activities, coordinated and interconnected by goals, time, tasks and place, conducted in a uniform design and plan of the government of specially designed system to protect maritime interests of the country and countering threats at sea;

- permanent activity of the authorized by law structures for monitoring, surveillance, inspection, and if necessary - imposition of sanctions to ensure compliance with the sovereign rights of the Republic of Bulgaria and the implementation of the norms of international maritime conventions.

The Republic of Bulgaria is a maritime nation and as such there are about $400 \mathrm{~km}$ coastline and Exclusive Economic Zone of approximately 36,000 square kilometers in the Black Sea. In its exclusive economic zone (which is about one third of our land area) Bulgaria holds the exclusive rights over the underwater and water resources, a potential that is not yet sufficiently developed.

The control of sea spaces comprises a group of activities that are linked functionally and organizationally:

- management of prevention activities in maritime transport;

- management of prevention activities in the exploitation of the resources of the sea;

- management of prevention activities in the coastal area;

- risk management at sea;

- providing "critical services“ at sea, the need of which arises from the use of the sea and the natural and technogenic risks;
- management of non-military crises in the sea areas;

- specialized control in the sea areas.

Definition of key terms/concepts

With the adoption in 2007 of An Integrated Maritime Policy for the European Union ${ }^{1}$, the concept of Marine (Maritime) spatial planning is introduced, which is a key instrument for the implementation of EU maritime policy.

In the document "A Guide to Evaluating Marine Spatial Plans", the term - Marine spatial planning (MSP) is defined as: „a public process of analyzing and allocating the spatial and temporal distribution of human activities in marine areas to achieve ecological, social, and economic objectives that are usually specified through a political process".[1]

Marine (Maritime) spatial planning assists national authorities and stakeholders in coordinating their actions to optimize the use of marine areas to benefit economic development and protection of the marine environment.

MSP in the national waters ${ }^{2}$ imply the multilateral analysis in all areas related to the activities in the sea. In the interest of obtaining a synergistic effect of the joint implementation of preventive actions, it is appropriate the questions of security, safety and environmental protection to unite in a common integral protective function. Bringing the organization of maritime sovereignty in accordance with the modified conditions of the environment becomes a matter of national importance. Not bringing this organization means underestimation of the problems with all the ensuing consequences - i.e. incomplete solving of the issues related to maritime security, safety and environmental protection.

\footnotetext{
${ }^{1} \operatorname{CoM}(2007) 575$ final

2 At international level, the national sea areas defined in the UN Convention on the Law of the Sea in 1982 , and at a national level - in Law on maritime spaces , inland waterways and ports of the Republic of Bulgaria .
} 


\section{"Mircea cel Batran" Naval Academy Scientific Bulletin, Volume XIX - 2016 - Issue 1 \\ Published by "Mircea cel Batran" Naval Academy Press, Constanta, Romania /I The journal is indexed in: PROQUEST / DOAJ / DRJI / JOURNAL INDEX / I2OR / SCIENCE LIBRARY INDEX / Google Scholar / Crossref / \\ Academic Keys / ROAD Open Access / OAJI / Academic Resources / Scientific Indexing Services / SCIPIO}

The security and safety environment at sea, can be seen as a set of dynamically changing external and internal conditions of operation and exploitation of the marine environment where the state realizes its political goals and protects its national interests. The status and changes in the environment on the one hand are a source of opportunities for implementation of the national interests, and on the other, a generator of risks and threats.

Security is one of the basic components in the hierarchical pyramid of human needs ${ }^{3}$, offered by the American psychologist Abraham Maslow, located immediately after physiological, which are the foundation of the pyramid. According to him, dissatisfaction with the needs of the lower levels does not allow for the satisfaction of these of the subsequent higher, i.e. if the needs of security are not satisfied, the necessary conditions for achieving social, prestigious and spiritual ones are not met. The pursuit of security is permanent and human characteristic feature inherent to all forms of human behavior.

Security is a dynamically evolving and multivariable concept that in the modern world is based on differently layered and dependent on each other levels. It depends on and it is focused on diverse subjects influenced by many factors determining the security environment.

In his monograph „Protection of maritime sovereignty" B. Mednikarov carry out a thorough study of the concept of security. [8] Such study, but related with the concept of safety, is also done by $\mathrm{K}$. Kolev in his monographs „Management of maritime safety“ [3] and „Management of Maritime Security" [4].

In connection with the definition of basic concepts concerning the purpose of this study, are accepted the following working definitions:

Maritime security is indivisible integral part of national and regional security system with increasing importance in all aspects. Prerequisites for maintaining its adequate and optimal condition are the timely identification of deliberate threats, risks and challenges and their prevention at their beginning.

Maritime security is focused on preventing the application of intentional damage to marine objects(ships, harbors) and their staff (crew) through sabotage, vandalism, illegal crime

\footnotetext{
${ }^{3}$ The hierarchical system of human needs graded from the lowest to the highest are: physiological , security, belonging, respect, confidence, self-actualization . This system has been presented for the first time in 1943 by Abraham Maslow in his article "Theory of Human Motivation " and later published and extended in the book
} "Toward a Psychology of Being". (trafficking of people, drugs, weapons, goods) terrorist and pirate activity.

Unlike security, the maritime safety is related to unintentional threats, risks and challenges. It is focused on the preservation and protection of human lives, material resources and the carried goods by the damaging effects of human errors, labor and the environment (under-utilized technologies, dangerous working conditions, still and moving underwater and surface navigation hazards, involuntary dangerous maneuver, tides, low or high temperatures, high humidity, earthquakes, hurricanes, etc.).

Environmental protection is linked to the human activities at sea disturbing natural systems that lead to their degradation and inflicting heavy damage on animate and inanimate nature, material resources / facilities, cargo / goods and people.

There are many negatively impacting conditions associated with damaging and injuries that cannot be assigned to maritime security, safety or the environmental protection, such as: violated law contracts (untimely and reduced payment of wages, excessive overtime workload leading to activities such as strikes, demotivation of staff, etc. : negligent performance of duties - perform only what could be checked, but under certain conditions, such an attitude has serious consequences; unfair competition by deliberately removing of goods and services from the market by excessively negative „tuned“ corrupt officials of central and local government; unfair competitive struggle between the institutions for a reallocation of funds, which under certain conditions leads to gross violations of human rights in shipping, etc. ). Essence of MSP

In marine areas is carried out a wide range of human activities - studies on the possibility of output oil and gas and the use of these fields, promote the development of alternative sources for the production of electrical energy (wind farms), develops shipping and fishing, and also used as a place for recreation and nature conservation. Due to increased demands on the marine ecosystem and exploitation of marine resources, it could leads to compromising of the future viability and use of marine space.

Marine and coastal activities are often closely linked. In order to promote sustainable use of marine space it is necessary to take into consideration the mutuality land - sea. Therefore the role of MSP will be very useful in determining the directions in relation to:

$>$ Sustainable and integrated management of human activities at sea. 
"Mircea cel Batran" Naval Academy Scientific Bulletin, Volume XIX - 2016 - Issue 1

Published by "Mircea cel Batran" Naval Academy Press, Constanta, Romania /I The journal is indexed in:

PROQUEST / DOAJ / DRJI / JOURNAL INDEX / I2OR / SCIENCE LIBRARY INDEX / Google Scholar / Crossref /

Academic Keys / ROAD Open Access / OAJI / Academic Resources / Scientific Indexing Services / SCIPIO

$>$ Construction, organization and management of protected environment (safety, security and environmental protection) in national maritime/marine areas (NMA) and cross-border areas.

$>$ The vulnerability of coastal ecosystems.

$>$ Social and economic factors and etc.

The levels of human activity are often incompatible with the maintenance and protection of important functions of the marine ecosystems, in some cases it could be considered even as a threat (eutrophication, biodiversity loss, damage to habitats and spread of invasive species and etc.). Marine ecosystem is influenced both by the activities carried out in the sea areas and of such conducted on land. Furthermore, improper use of maritime spaces could lead to competition and conflicts between users.

In this regard, maritime spatial planning is a useful and cost-effective tool that can support the development of integrated management of the security level in the maritime areas. So far, the planning of a certain marine area was focused on individual sectors, but now MSP is aimed at balancing the various human activities at sea by integrating policies and objectives in various sectors and helps to solve potential conflicts in the use of marine spaces, while paying attention to environmental protection. MSP is a practical way to create and establish the organization of the use of maritime space and the interaction between its users to balance the demands for development with the need to protect marine ecosystems, as well as outstanding achievement with a social and economic objectives in a planned way and in a protected environment. Intersectoral planning allows to ensure long-term operation and sustainable use of marine resources.

In 2009, UNESCO has published a guidance for $\mathrm{MSP}^{4}$, where they presented the main characteristics of effective MSP [5]:

$>$ Ecosystem-based, balancing ecological, economic, and social goals and objectives toward sustainable development.

$>$ Integrated, across sectors and agencies, and among levels of government.

$>$ Place-based or area-based.

$>$ Adaptive, capable of learning from experience.

$>$ Strategic and anticipatory, focused on the long-term.

> Participatory, stakeholders actively involved in the process.

\section{Integrated management}

Effective and integrated maritime spatial management is considered crucial to mitigate conflicts and a further deterioration of the Black Sea environment and proactive planning to avoid future potential conflicts (concerning the security of the sea), including those related to climate changes.

Management of marine resources in the Black Sea region is characterized by - a sector or an individual case. Certain areas in the sea may be designated for specific activities without a clear overall vision for their use and resources. Management, sector by sector, is not always sufficient in diverse human activities affecting marine areas, as it does not take into consideration the interaction, potential conflicts or compromises between the performed activities and the cumulative effects over the climate and sea areas.

The lack of clear vision and integrated planning concerning the use of marine areas and resources is a major cause of increased arising of conflicts between different users, leading to a risk of deterioration of the environment. The problems are exacerbated by shortcomings and inadequacy of regulations, fragmented jurisdiction and unclear policies. Therefore, management activities in marine areas need to apply integrated maritime spatial planning.

In the guidance for Maritime Spatial Planning of UNESCO, MSP does not end with a single preparation of a plan, and it's a constantly evolving process (Fig. 1) of adapting to current and prospective changes in the conditions of the maritime domain. Development and implementation of MSP includes the following steps [5]:

1) Identifying need and establishing authority;

2) Obtaining financial support;

3) Organizing the process through preplanning;

4) Organizing stakeholder participation;

5) Defining and analyzing existing conditions;

6) Defining and analyzing future conditions;

7) Preparing and approving the spatial management plan;

8) Implementing and enforcing the spatial management plan;

9) Monitoring and evaluating performance;

10) Adapting the marine spatial management process.

\footnotetext{
${ }^{4}$ Marine spatial planning - A Step-by-Step Approach toward Ecosystem-based
} Management 
"Mircea cel Batran" Naval Academy Scientific Bulletin, Volume XIX - 2016 - Issue 1

Published by "Mircea cel Batran" Naval Academy Press, Constanta, Romania // The journal is indexed in:

PROQUEST / DOAJ / DRJI / JOURNAL INDEX / I2OR / SCIENCE LIBRARY INDEX / Google Scholar / Crossref /

Academic Keys / ROAD Open Access / OAJI / Academic Resources / Scientific Indexing Services / SCIPIO

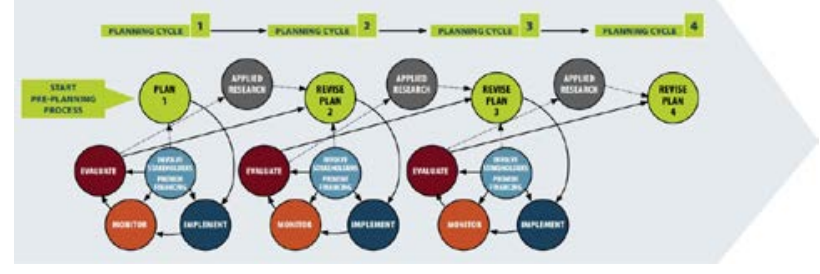

Fig. 1 Continuous cycle of MSP (Sourse: MSP - A Step-by-Step Approach toward Ecosystem-based Management)

MSP is not simply a linear process with a beginning and end. This is a complex process in which besides straight lines it is necessary to provide and feedbacks. This allows set at the beginning of the planning process goals and objectives to change over the time, as costs and benefits of the taken measures shall be established later in the process of revision and subsequent planning. The analysis of the impacts of current and prospective conditions change with the insertion of new information into the planning process. Planning is a dynamic process of preparing to control reactions in occurrence of negative changes. The responsible authorities should form abilities to respond the changes.

Zoning of marine areas

Planning and management of the national maritime areas can be done to human activities, but cannot carry out such actions over marine ecosystem or its components. Separation of the maritime area of specific marine areas (zoning) should be done depending on the activities performed at sea, for example, to develop or maintain a given area, areas with specific uses and others.

For some areas of the NMA could be said, that they have a greater importance than others by environmental, military or economic terms. Species, habitats, populations, deposits of natural resources, shipping and military areas are all distributed in different locations and with differing timing. Zoning can be done to geographical and / or timing principle to minimize conflicts in areas where different activities compete on spatial or temporal basis.

Most of the countries applying MSP are using zoning of marine areas related to human activities at sea, such as shipping, development of oil and gas extraction, offshore renewable energy, aquaculture, environmental protection and others. The problem that arises is that usually this is done in a given area or for a specific case, without taking into consideration the effects caused by

51 other human activities or the marine environment. This leads to two main types of conflicts [5]:

$>$ Conflict between human needs (user-user);

$>$ Conflict between human needs and the marine environment (user - ecological environment).

For areas not applying MSP the responsible authorities are only able to react to events when it is already too late. On the other hand, MSP is a process oriented to planning and the ability to choose a course of action that leads to the desired outcome.

Current status of MSP

In recent years, several countries applied MSP to reduce conflicts and to promote a sustainable use of marine resources. Such examples can be given to projects related to: the Great Barrier Reef, National Marine Reserve in the United States and the initiative of governing the shelf in the East Scotia in Canada.

Several countries in Europe have also taken steps to develop MSP in a wider context, or on its own initiative or policy driven by the EU legislation. In 2009, Britain adopted a law "Marine and Coastal Access Act", whose aim is to present the vision "clean, safe, productive and biologically diverse oceans and seas" and to improve coastal access. An important part of this process is the establishment of a strategic system for marine planning to ensure a more efficient and sustainable use of marine resources in the UK. In 2009, the Netherlands has developed a framework for spatial planning for the Dutch part of the North Sea „Integrated Management Plan for the North Sea 2015" while in Germany is prepared framework for spatial planning, including a draft for spatial planning and environmental assessment of the German exclusive economic zone (EEZ) aimed at ecological and economical use of the German waters.

Belgium is among the first countries began implementation of spatial planning, covering both the territorial sea and exclusive economic zone solving a wide range of marine interests. The plan was adopted in 2003 and phased in.

In Portugal, the National Strategy for the Seas (2006) seeks to integrate the policies of different sectors and to define principles for maritime spatial planning and integrated coastal zone management. In 2007 was founded interministerial committee for maritime affairs.

Norway has developed an Integrated Management Plan for the Barents Sea and the sea area off the islands of Lofoten. It presents a framework for sustainable use of the resources for existing and new activities. Take into 


\begin{abstract}
"Mircea cel Batran" Naval Academy Scientific Bulletin, Volume XIX - 2016 - Issue 1
Published by "Mircea cel Batran" Naval Academy Press, Constanta, Romania /I The journal is indexed in: PROQUEST / DOAJ / DRJI / JOURNAL INDEX / I2OR / SCIENCE LIBRARY INDEX / Google Scholar / Crossref /

Academic Keys / ROAD Open Access / OAJI / Academic Resources / Scientific Indexing Services / SCIPIO
\end{abstract}

consideration the fact that the marine environment is changing over time and emphasizes the importance of scientific knowledge. Norway intends to develop integrated management plans for the Norwegian Sea and the Norwegian part of the North Sea.

Furthermore the practices related to unilaterally maritime spatial planning, in Europe is monitored the realization of several international projects (Fig. 2) as follows:

> Plan Bothnia - preparation for Maritime Spatial Planning in the Baltic Sea (2010 - 2012);

$>$ BaltSeaPlan - a draft program for the Baltic Sea Region „Introducing Maritime Spatial Planning in the Baltic Sea“ (2009 - 2012);

$>$ Transboundary planning in European Atlantic waters (TPEA) - Project on Maritime Spatial Planning in the Atlantic, including Celtic Sea and the Bay of Biscay (2012 - 2014);

$>$ ADRIPLAN - MSP in the Adriatic and Ionian Sea (2013 - 2015);

$>$ Baltic SCOPE - Transboundary solutions for maritime spatial planning in the Baltic Sea (2015 - 2017).

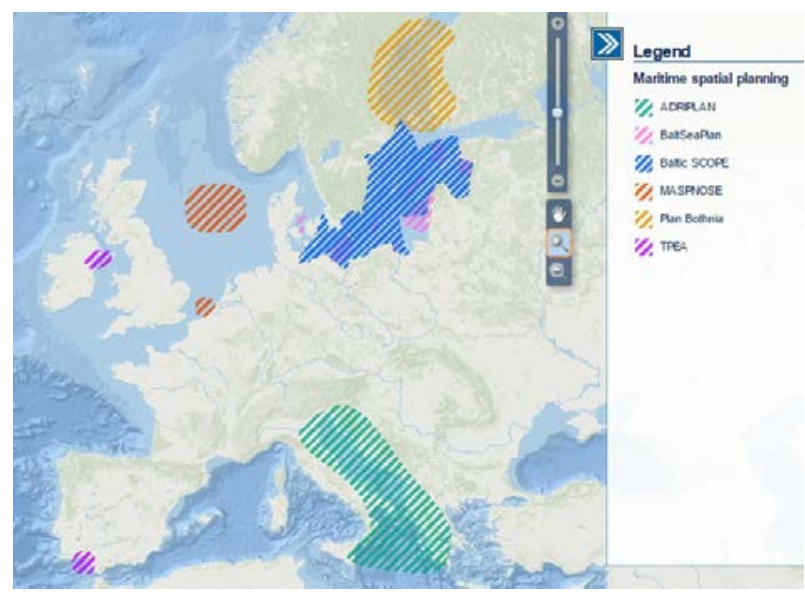

Fig. 2 Map of projects related to MSP (Sourse: European Atlas of the Seas)

In addition to these projects in the period 2006 2008, the regional administrations Varna was a partner in the implementation of the project PlanCoast - a project under the program INTERREG III B CADSES for a sustainable development of marine and coastal areas of the Baltic, Adriatic and Black Sea „Spatial Planning in Coastal Zones". The project is aimed at supporting sustainable and viable development of coastal areas through the application of tools for intended use of the sea and management of the activities related to the sea.
According to information of the Ministry of regional development and public works of Bulgaria on October 2015, the project "Cross-border maritime spatial plan for the Black Sea - Romania, Bulgaria" or "MARSPLAN - BS", which lasts two years, officialy started. Project activities include: initial assessment,as an analysis of the Romanian and Bulgarian marine environment, identification of general challenges in the maritime area on both sides, conducting a detailed study to create a new navigation system in the territorial waters of Bulgaria and Romania and the review of the institutional and regulatory framework for the maritime spatial planning (MSP) in the Black Sea. The implementation of the project also includes preparation of cross-border cooperation in MSP related to the creation of an institutional framework for cooperation on cross-border MSP. It is also invisioned the creation of a monitoring system for the Black Sea region by developing a common spatial database for marine areas in Romania and Bulgaria, determination of indicators for monitoring and control and appropriate procedures for their introduction.

Implementation of maritime spatial planning in the interest of protection

In 2015-2016, specialists from the Nicola Vaptsarov Naval Academy, together with Basin directorate „Black Sea Region“ - Varna and Varna Regional Administration, are working on the project „Integrated Information System for maintenance the management of the coastal area“, financed by the program BG02 „Integrated management of marine and inland waters".

The Working Group has performed a comprehensive analysis of the security and safety in sea areas, which shows that it is characterized by dynamism and growing unpredictability. Working in such an environment necessitates the possession of the necessary information and forecast of its behavior, the timely detection of dynamic changes in a wide range of parameters that characterize it in order to respond adequately and maintain steady state of safety and security. Researchers believe that the establishment of an integrated information system to support the management of the coastal zone is a key element in the system for monitoring of the marine environment and a respond to changes in its parameters in accordance with the environmental standards, safety standards of the infrastructure and personnel and norms of the Maritime security. In recent years there has been a significant increase in the use of marine areas for a variety of purposes. The research group has prepared a document "Zoning of the coastal area of the 
"Mircea cel Batran" Naval Academy Scientific Bulletin, Volume XIX - 2016 - Issue 1

Published by "Mircea cel Batran" Naval Academy Press, Constanta, Romania /I The journal is indexed in: PROQUEST / DOAJ / DRJI / JOURNAL INDEX / I2OR / SCIENCE LIBRARY INDEX / Google Scholar / Crossref /

Academic Keys / ROAD Open Access / OAJI / Academic Resources / Scientific Indexing Services / SCIPIO

Republic of Bulgaria“, where are distinguished and discussed in details six groups of areas:

$>$ Aquaculture, fishing, protected natural objects.

$>$ Underwater cultural heritage, Tourism.

$>$ Exploration, extraction and exploitation of oil, gas and other energy resources, mining, trails of underwater pipelines, renewable energy.

$>$ Maritime transport routes and traffic.

$>$ Military activities.

$>$ Critical Infrastructure.

In addition to marine areas, pressure also turns on coastal resources, which requires planning and management.

Methodology based on four phased approach developed by the American branch organizations and institutions providing guidance in carrying out hazard analysis in the interest of protection of objects in the sea areas. [3]

$>$ Stage 1: Analyzing the dangers - to reveal the sources and types of hazards and the probability of their realization

$>$ Stage 2: Analyzing vulnerabilities - to reveal possible scenarios for the realization of credible hazards.

$>$ Stage 3: Carry out preventive activities enhances the level of security and safety by implementing preventive activities to prevent and neutralize the realization of hazards.

$>$ Stage 4: Restrictive reactions when occurring emergencies - manage such situations in the realization of hazards and limiting the possible consequences.

Activities carried out in the separated areas, unless a positive impact on the employment, production, economic opportunities, investments, etc., exert also a negative impact. For the needs of the paper in Table 1 is considered the interrelation: endangered object - a source of threat - action area „Exploration, extraction and exploitation of oil, gas and other energy resources, mining, trails of underwater pipelines, renewable energy".

Table 1

\begin{tabular}{|l|l|}
\hline \multicolumn{1}{|c|}{$\begin{array}{c}\text { Source of danger / } \\
\text { threat }\end{array}$} & \multicolumn{1}{c|}{ Action } \\
\hline \multicolumn{1}{|c|}{1} & \multicolumn{1}{c|}{2} \\
\hline \multicolumn{2}{|c|}{ Endangered object: Oil / gas-extraction platform } \\
\hline $\begin{array}{l}\text { Ship not under } \\
\text { command and } \\
\text { underway. }\end{array}$ & $\begin{array}{l}\text { 1. Collision with } \\
\text { platform. } \\
\text { 2. Pipeline ruptures. }\end{array}$ \\
\hline $\begin{array}{l}\text { Sabotage caused by } \\
\text { insiders, by damaging } \\
\text { or destroying: }\end{array}$ & $\begin{array}{l}\text { 1.Unauthorized release } \\
\text { of hazardous } \\
\text { substances. }\end{array}$ \\
\hline
\end{tabular}

53

\begin{tabular}{|c|c|}
\hline $\begin{array}{l}\text { - The structure of } \\
\text { the platform; } \\
\text { - An element of the } \\
\text { management and } \\
\text { control. }\end{array}$ & $\begin{array}{l}\text { 2. Violation of the } \\
\text { integrity of pipelines. } \\
\text { 3. Rush and ignite of a } \\
\text { large quantity of } \\
\text { petroleum products. } \\
\text { 4. Turning off of vital } \\
\text { systems. }\end{array}$ \\
\hline $\begin{array}{l}\text { Bad } \\
\text { hydrometeorological } \\
\text { conditions (extremely } \\
\text { strong winds and sea } \\
\text { waves). }\end{array}$ & $\begin{array}{l}\text { 1. Detachment of } \\
\text { surface offshore } \\
\text { facilities from their } \\
\text { anchors. } \\
\text { 2. Marine pollution } \\
\text { arising from spills of } \\
\text { oily substances. }\end{array}$ \\
\hline $\begin{array}{l}\text { Act of terrorism by: } \\
\text { - attack and gained } \\
\text { control over the } \\
\text { platform; } \\
\text { - attack by a loaded } \\
\text { with explosives boat; } \\
\text { - attack by air or } \\
\text { under water. }\end{array}$ & $\begin{array}{l}\text { 1. Use the platform as } \\
\text { ecological weapon. } \\
\text { 2. Death of staff. } \\
\text { 3. Marine pollution } \\
\text { arising from spills of } \\
\text { oily substances. }\end{array}$ \\
\hline $\begin{array}{l}\text { Activation of geological } \\
\text { processes } \\
\text { (earthquakes). }\end{array}$ & $\begin{array}{l}\text { 1. Rupture of } \\
\text { underwater pipelines. } \\
\text { 2. Marine pollution } \\
\text { arising from spills of } \\
\text { oily substances. }\end{array}$ \\
\hline $\begin{array}{l}\text { Technical defects due } \\
\text { to: } \\
\text { - fatigue of the } \\
\text { material; } \\
\text { - faulty } \\
\text { workmanship. }\end{array}$ & $\begin{array}{l}\text { 1. Break in the } \\
\text { pipelines and their } \\
\text { exhausting valves. }\end{array}$ \\
\hline 1 & 2 \\
\hline Industrial pollution. & $\begin{array}{l}\text { 1. Marine pollution } \\
\text { arising from spills of } \\
\text { oily substances. }\end{array}$ \\
\hline $\begin{array}{l}\text { Unintentional errors } \\
\text { caused by insiders (due } \\
\text { to negligence). }\end{array}$ & $\begin{array}{l}\text { 1. Release of } \\
\text { dangerous substances. } \\
\text { 2. Caused a fire or } \\
\text { explosion. } \\
\text { 3. Death of staff. }\end{array}$ \\
\hline $\begin{array}{l}\text { Breakthrough in the } \\
\text { Information System } \\
\text { (IS). }\end{array}$ & $\begin{array}{l}\text { 1. Unauthorized remote } \\
\text { control of the IS. } \\
\text { 2. Security break in } \\
\text { objects with access } \\
\text { control. } \\
\text { 3. Replacement of } \\
\text { information data. }\end{array}$ \\
\hline \multicolumn{2}{|c|}{$\begin{array}{l}\text { Endangered object: Trails of underwater } \\
\text { pipelines (prospective) }\end{array}$} \\
\hline $\begin{array}{l}\text { Sinking of a ship and } \\
\text { break in the pipeline. }\end{array}$ & $\begin{array}{l}\text { 1. Marine pollution } \\
\text { arising from spills of } \\
\text { oily substances. }\end{array}$ \\
\hline \multicolumn{2}{|c|}{$\begin{array}{l}\text { Endangered object: Renewable energy sources } \\
\text { (prospective) }\end{array}$} \\
\hline
\end{tabular}


"Mircea cel Batran" Naval Academy Scientific Bulletin, Volume XIX - 2016 - Issue 1

Published by "Mircea cel Batran" Naval Academy Press, Constanta, Romania /I The journal is indexed in:

PROQUEST / DOAJ / DRJI / JOURNAL INDEX / I2OR / SCIENCE LIBRARY INDEX / Google Scholar / Crossref /

Academic Keys / ROAD Open Access / OAJI / Academic Resources / Scientific Indexing Services / SCIPIO

\begin{tabular}{|l|l|}
\hline Collision at sea with: & 1. Death of staff. \\
- Ship not under & 2. Marine pollution \\
command and & arising from the spill \\
underway & and ignition of oily \\
- a ship, due to a bad & substances. \\
hydrometeorological & 3. Failure of source and \\
conditions. & $\begin{array}{l}\text { supply interruption of } \\
\text { electricity. }\end{array}$ \\
\hline
\end{tabular}

After clarifying the correlation endangered object source of danger - strike effect it is appropriate to apply the methodology for risk analysis for each zone. Using a preset analysis for hazards and/or threats we can determine the possible source of danger/threat. This would help in qualifying the events and conditions of consequence occurrences, and the type of strike effect. Using the methods - vulnerabilities tree analysis and events tree we can determine the probability of dangerous phenomenon occurrences, and the severity of the consequences when they occur. To establish a scenario for the development of a particular hazard / threat, the method - analysis of tree scenario that creates the foundation for an actual risk management can be used. The use of this method allows for the establishment of the critical response time, the state of manageability, the location and characteristics of the barriers of defense.

Dangers and threats are possible events, conditions for the emergence of serious consequences. It could be said that the source of impact will never act independently and only from one direction, and usually this will happen by the overlay of several sources of danger / threat. The risk $(R)$, as a parameter for assessment is seen as a function of the severity of the possible consequences $(C)$ from a hazard / threat and the probability $(P)$ for its implementation:

$$
R=f(C, P)
$$

When the effect of the impact is great in and there is a high probability of realization of the danger / threat, the risk level is high, which is an unacceptable security option The opposite statement is also true - if the effect of the consequences is small at a low probability of realization of the danger / threat, the risk level is also low, which may be an eligible security option. Based on this information, the correct risk assessment of a danger or threat, would help to improve the security level. Making a wellgrounded decision and the impact of reducing the burden of the consequences and I or the probability of realization enables us to reduce the risk and improve the security level in the planning process.
The interaction between the system elements People - Technology - Marine environment (Fig. 3 ) is related to the activity carried out in the maritime space. It ensures its purpose, but it is also a source of risk caused bythe dangers and threats related to the activities performed at sea. The impact between the elements have both ordinal and inverse relation. A man can be seen as an essential element of the system that serves and manages the technologies thus affecting and changing the maritime environment. On the other hand, he is exposed to the effects of the technology which he operates as well as to the consequences of the altered marine environment. Risk management should be an essential part in ensuring the process of maritime planning. For this purpose, it must cover the entire functionality of the management system and to reveal the correlation between the component and the elements.

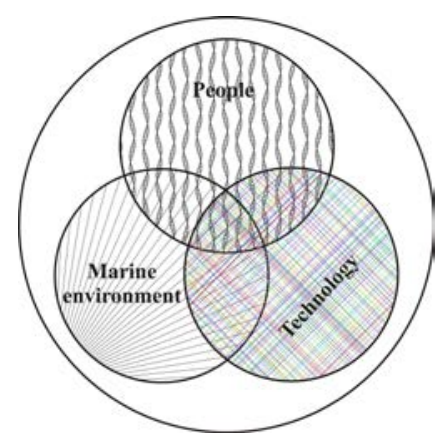

After an analysis and risk assessment, the manner of impact, for the purpose of ensuring the security and safety of the performed activities at sea, may consider various options for reducing or eliminating the consequences of a particular hazard / threat. Possible models of impact are:

$>$ Model Domino - presents the danger I threat as an event occurring in a particular sequence. Interruption at a given moment (the removal of a domino) would prevent striking effect or reduce its effect.

$>$ Barrier Model - this model shows that the conduct of human activity in combination with the conditions of the marine environment are able to lead to the realization of the source of danger I threat and technological provision of the system may prevent the realization of such a situation. In turn the barriers may be a static or dynamic type. [3]

In order to ensure an environment of security and safety in the maritime environment monitoring control and evaluation of activities in the separate areas is needed. This is achieved by carrying out: 


\begin{abstract}
"Mircea cel Batran" Naval Academy Scientific Bulletin, Volume XIX - 2016 - Issue 1
Published by "Mircea cel Batran" Naval Academy Press, Constanta, Romania // The journal is indexed in: PROQUEST / DOAJ / DRJI / JOURNAL INDEX / I2OR / SCIENCE LIBRARY INDEX / Google Scholar / Crossref /

Academic Keys / ROAD Open Access / OAJI / Academic Resources / Scientific Indexing Services / SCIPIO
\end{abstract}

$>$ Radar and / or visual observation of abovewater and air environment in areas - it is conducted continuously and accidental. The indicators of monitoring are floating and flying objects.

$>$ Hydro acoustic monitoring of the underwater environment in the regions. It is conducted continuously, periodically and accidental. The indicators of monitoring are underwater objects.

Fig. 3 System: People - Technology Marine environment
$>$ Monitoring of hydro meteorological conditions in the areas (wind, waves water temperature, air flow, air pressure and humidity). It is conducted is continuously. It is organized with the help of specialized equipment on shore and floating platforms.

$>$ Environmental monitoring to establish spills of petroleum products. It is conducted periodically and accidental. It is performed by visual, radar and laboratory methods.

\title{
CONCLUSION
}

The environment in the Black Sea region is under increasing risk because of the potential increase of hazards and threats affecting the activity carried out in the maritime areas. The implementation of maritime spatial planning and continuous monitoring of the environment would help in providing quality control on the security level (maritime safety and security and environmental protection) of marine areas.

MSP is no longer just a theoretical concept. Rather, it is a practical process that is used in many parts of the world ocean, including disclosed reserves for expansion of activities in the maritime areas. In 2014 , about 40 countries worldwide have either already implemented or are in the final stage of development a MSP for its marine areas.

In the final provisions of Directive 2014/89 / EU (establishing a framework for Maritime Spatial Planning) has accepted the EU Member States to transpose it into their national legislation and by September 2016 to designate the competent authorities responsible for the implementation of MSP. Also, the Member States are required by 2021 to prepare their national maritime spatial plans. In realizing these plans, countries are free to adjust the content of plans and strategies to their specific economic, social and environmental priorities and the objectives of their national sectoral policies and law, in compliance with the minimum requirements set out in the directive.

As a result the following conclusions could be done:

$>$ MSP is a process that should prevent the arising of conflicts in the activities performed at sea, such as the successful management of marine areas are needed managers who can work with spatial and temporal diversity of the marine environment.

$>$ Upon implementation of MSP, authorized authorities should plan in direction of providing preventive activities rather than planning to offset the effects of realized threat / danger.

$>$ The implementation of MSP in the interest of security level, an integrated method is needed, i.e. considering the separate zones, type of equipment and the variety of the controled parameters, coupled with the implementation of reliable control for which appropriate use of various tools and platforms that can act as necessary in various conditions of the situation.

$>$ Legal designation of competent authorities and the delegation of the necessary rights, obligations and responsibilities as well as financial support to these authorities and the people concerned.

\section{BIBLIOGRAPHY}

[1] A Guide to Evaluating Marine Spatial Plans.

<http://unesdoc.unesco.org/images/0022/002277/227779e.pdf>, 25.03.2016, 19:57.

[2] HANDBOOK on Integrated Maritime Spatial Planning from the INTERREG III B CADSES PlanCoast Project. <http://www.plancoast.eu/files/handbook_web.pdf>, 16.03.2016, 22:54.

[3] Kolev, K. Management of Maritime safety. STTENO Publishing House, Varna, 2012. ISBN 978-954-449601-2. 464 pp.

[4] Kolev, K. Management of Maritime Security. STENO Publishing House, Varna, 2014. ISBN 978-954-449756-9. 256 pp.

[5] Marine spatial planning - A Step-by-Step Approach toward Ecosystem-based Management. <http://www.unesco-ioc-marinesp.be/uploads/documentenbank/d87c0c421da4593fd93bbee1898e1d51.pdf>, 27.03.2016, 15:33.

DOI: 10.21279/1454-864X-16-I1-009 
"Mircea cel Batran" Naval Academy Scientific Bulletin, Volume XIX - 2016 - Issue 1

Published by "Mircea cel Batran" Naval Academy Press, Constanta, Romania // The journal is indexed in: PROQUEST / DOAJ / DRJI / JOURNAL INDEX / I2OR / SCIENCE LIBRARY INDEX / Google Scholar / Crossref / Academic Keys / ROAD Open Access / OAJI / Academic Resources / Scientific Indexing Services / SCIPIO

[6] Marine spatial Planning in the Nordic region - Principles, Perspectives and Opportunities. Nordic Council of Ministers, Copenhagen 2009, ISBN 978-92-893-1856-3.

[7] Maritime Spatial Planning in the EU - Achievements and Future Development. <http://ec.europa.eu/maritimeaffairs/documentation/publications/documents/com_2010_771_brochure_bg.pd $\mathrm{f}>$, 20.03.2016, 21:33.

[8] Mednikarov, B. Protection of maritime sovereignty. NVNA, Varna, 2008. 467 pp.

[9] Roadmap for Maritime Spatial Planning: Achieving Common Principles in the EU. <http://www.europarl.europa.eu/meetdocs/2004_2009/documents/com/com_com(2008)0791_/com_com(200 8)0791_bg.pdf>, 14.03.2016, 20:18. 